Gender Mainstreaming Manual - A book of practical metbods from the Swedish Gender Mainstreaming Support Committee (Jamstöd) (Swedish Government Official Reports SOU 2007: 15)

Lestál Zsuzsanna (szerk.) (2008): Nemre való tekintettel. Kézikönyy a nók és férfake közötti társadalmi egyenlöség érvénvesitééének elméletéél és gyakorlatáról (intézmények és vállalkozásole vezetöi számára). Budapest E/004. számú Fejlesztési Partnerség. Interneten:

hol/ www.berbarometer.hu/main/hirek/nok/nemre-valo-tckintettel (letöltve: 2010. január 12.)

McKay, Ailsa. (2004): Developing a Gender Budget Initiative - A Question of Process or Polig?? Lesson Iearned from the Scottish Experience (Chapter prepared for Vol 4 of University of Linz, Gende Studies series. December 2004 - Glasgow Caledonian University Glasgow, Scotland and Scottish Womens Budget Group). Interneten:

Scottish Womens Budget Group). Interneten: 12.)

Petô, Andrea (2008): A Nök és férfiak története Magyarországon a bosszú 20. sqázadban. Budapest Szociális és Munkaügyi Minisztérium.

Verloo, Mieke (2001): Another velvet revolution? Gender mainstreaming and the politics of implementation IWM Working Paper No. 5/2001 Vienna. Intemeten:

http://www.iiav.nl/epublications/2001/anothervelvetrevolution.pdf (letöltve: 2010. január 12.)

Verloo, Mieke és Roggeband, Conny (1996): Gender Impact Assessment: The Development of a mew Instrument in the Netherlands. Impact Assessment 14(1): 3-21
BOGNÁR ADRIENN

\section{A politikai szocializáció egyes jellegzetességei a fiatalok} körében

\section{Bevezető}

A rendszerváltozást megelổzően, de még inkább az azt közvetlenül követô Aévekben számos kutatás vizsgálta a fiatalok politikai beállitódásait, a politikai szocializációt, az ifjúság politikai aktivitását. Manapság azonban - a téma fontosságához képest - kevesebb olyan átfogó vizsgálat készül, amelyek nem általánosságban az ,ifjúságot”, hanem a politikai szocializáció napjainkra jellemzô specifikumait, a fiatalok politikához való viszonyát, politikai magatartását és politikai aktivitását vizsgálja. Ezért is tarthatjuk kiemelkedő jelentőségűnek a 2008-ban végzett „Iskola és társadalom” kutatást.

A téma vizsgálata azért is különösen érdekes az ezredfordulót követô években, mert rendkívül sok olyan tényező befolyásolhatja az országban élők - így a fiatalok - politikai magatartását, amelyek korábban nem kerültek a figyelem középpontjába. Ilyen például a sok esetben gyülöletkeltésig fajuló marakodás a két nagy párt között, amely nemcsak a családokban, hanem a baráti társaságokban, munkahelyi közösségekben zajló diskurzusokat is befolyásolja, és amely olyan személyeket is „bevont” a ,politikába”, akik korábban nem mutattak érdeklődést iránta. Ezzel szemben áll egy másik hatás, amelynek következménye a politikából való „,kiábrándultság”, amit jól példáz az is, hogy nem csupán az országos politika, de sok esetben még a lokális érintettség sem sarkallja tettekre a lakosságot (példaként említhetô a pécsi lokátor építésével kapcsolatban tartott népszavazás, amit érvénytelenné nyilvánítottak az alacsony részvétel miatt) Rendkivüli események (például a Magyar Televizió székházánál történt erőszakos cselekmények) is felhívják a figyelmet arra, hogy behatóbban kell foglalkoznunk nem csupán az egyes jelenségekkel, de ezek okaival is.

A politikai aktivitás (inaktivitás) kapcsán megállapítható, hogy a kilencvenes évek vizsgálatai a fiatalok politikai érdeklődésének hiányára, alacsony cselekvési késztetettségére mutatnak rá. $\mathrm{E}$ vizsgálatok kimutatták azt a tendenciát, hogy még e korcsoporton belül is eltérő politikai érdeklỏdéssel és aktivitási igénnyel jellemezhetőek a fiatalok. Az ifjúsági korfán felülrôl lefelé haladva egyre nôtt a politika iránti közöny (Gazsó és Laki 2004: 172-177).

A kutatások rávilágitottak arra is, hogy a fiatalok politikai érdeklődése nem minősíthetô folyamatosnak és magas intenzitásúnak, hanem inkább eseti jellegũnek. A 2000-es és 2004-es kutatások sem mutattak trendszerũ változást. A kutatások eredményei szerint az ifjúság számára a politikai szféra átláthatatlan, 
távoli és általuk egyáltalán nem befolyásolható világ. A nem hivatásszerü politizálást eredménytelennek tartják, míg a hivatásszerū politizálás presztízse olyanynvira alacsony számukra, hogy annak keretei között sem szeretnének tevékenykedni. A fiatalok sokkal inkább egyéni boldogulásukat tartják szem elôtt, egyéni céljaikat igyekeznek elérni egyéni utakon, nem pedig kollektív formákban (Gazsó és Laki 2004: 174).

Az Ifjúság2004 és az Ifjúság2008 kutatási beszámolója is hasonló megállapítá sokat fogalmaz meg. E kutatások adatai is azt bizonyítják, hogy a fiatal nemzedék politikai aktivitása alacsony szintũ. Ez igaz a választásokon való részvétel, a civil szervezeti tagság, valamint a politikai szervezetekhez való tartozás dimenziójában egyaránt (Bauer-Szabó 2005: 76, 79-81).

A négy évvel korábbi vizsgálathoz képest is csökkenő tendenciát tükröz a 2008-as kutatás a politikai aktivitás kapcsán. A 2008-as kutatás eredményei szerint egy, az adatfelvétel idején esedékes választáson a kérdezett fiatalok megközelítőleg harmada venne részt, és csupán 6\%-uk tagja valamilyen ifjúsági szervezetnek, míg a politikai szervezeti tagság még ennél is kisebb arányban jellemzô rájuk: hozzávetőlegesen egy százalékuk tagja politikai szervezetnek. A kutatások által alátámasztott passzivitás azonban nem jelenti azt, hogy bizonyos szituatív tényezök nem okozhatnak változást, amely során nagyobb méretủ csoportok aktivizálódnak (Bauer és Szabó 2009: 107, 114-119).

\section{Az „Iskola és társadalom” kutatás}

A fent említett „Iskola és társadalom” kutatás egy 2005-ös kutatás folytatásának tekinthetô. A kutatás vezetôje Csákó Mihály, a baranyai adatfelvételt a Pécsi Tudományegyetem Bölcsészettudományi Karának Szociológia Tanszéke koordinálta és végezte. ${ }^{1}$ A vizsgálat célja között szerepelt a középiskolások demokráciaképének felmérése, az iskolai demokrácia vizsgálata, valamint a fiatalok politikához való viszonyának elemzése. A kutatás elméleti kerete a politikai szocializáció ismert fogalmi szerkezetére támaszkodik, a politikai szocializációt, a szocializációs folyamat részeként kezeltük. Ennek főbb ágensei közül (család, kortársak, iskola, média) az iskola került a vizsgálat fókuszába.

$\mathrm{Az}$ adatfelvétel öt megyében (Hajdú-Bihar, Baranya, Szabolcs-Szatmár Bereg, Csongrád és Fejér megyében) és a fövárosban történt 9. és 11. évfolyamos középiskolások körében. Az iskolatípusta és évfolyamra reprezentativ minta elemszáma 5962 fö.

Jelen tanulmányban a középiskolások politikához való viszonyára, a politikával kapcsolatos érdeklődésre, ismeretekre, valamint a politikai aktivitásta vonatkozó néhány kérdésre adott válaszok eredményeit mutatom be.

\section{Politikával kapcsolatos kommunikáció}

Kutatásunk során vizsgáltuk, hogy a középiskolások családjában a politika mint téma milyen helyet foglal el a hétköznapi családi konverzációkban. A különbözõ témák csoportosítása során Szabó Ildikó (2009) témakonstrukcióit használtam fel. Adataink alapián megállapíthatjuk, hogy a fiatalokkal a családon belül elsôsorban az iskolai témákkal kapcsolatban beszélgetnek (például tanulmányi eredmények, iskolai élet, öltözködés). Ezt követỏen a családi beszélgetések során a mediatizált témák kerülnek szóba (például televíziós mủsorok, médiaszereplök, bulvárhírek, sztárok, híres emberek, zenei ízlés, zenészek, együttesek). A praktikus témák szintén viszonylag magas arányban képezik a családi diskurzusok tárgyát (a másik nemmel való kapcsolat, bũnözés, kisebbségek, egészség, betegség, családi gazdálkodás, pénz, rokonok életvitele, szegénység, szülők munkája). Legkevésbé a politikai témák (politikusok, belpolitikai ügyek, külpolitikai ügyek, politikai pártok, helyi önkormányzati ügyek, más szervezetek, mozgalmak), valamint az elvont témák (vallási, világnézeti kérdések, környezetszennyezés, magyarság) kerülnek szóba a hétköznapi családi kommunikáció során.

Eredményeink szerint a szakmunkásképzôbe járó fiatalokat veszi körül a legszegényebb kommunikációs tér; az ô családjukban kerül szóba a legkevesebb fent megjelölt témakör. Ezzel szemben a gimnazisták kommunikációs környezete a legváltozatosabb, ôk beszélgetnek otthon a legtöbb témáról, és az ő családjukra jellemző leginkább a politikai témáról való diskurzus is. A politikai témák kapcsán megállapítható az is, hogy a 11. évfolyamta járó középiskolásokkal szignifikánsan magasabb atányban beszélgetnek a családban ilyen tárgykörben, mint a 9. évfolyamos tanulókkal.

Adataink tanúsága szerint a középiskolások valamivel több mint harmada egyáltalán nem beszélget politikai témákról, lcgmagasabb arányban pedig a szülổkkel való kommunikáció során kerül szóba ez a témakör. 


\begin{tabular}{|c|c|c|c|}
\hline Témakianize & Mintacitlag & 9. Enfolyam & 11. évfolyam \\
\hline \multicolumn{4}{|l|}{ Iskalai témák } \\
\hline Tanulmányi eredmények & 93,0 & 94,1 & 92,0 \\
\hline Iskolai élet & 90,3 & 91,6 & 89,0 \\
\hline Öltözködés & 77,2 & 78,2 & 76,4 \\
\hline \multicolumn{4}{|l|}{ Mediatizált témák } \\
\hline TV mũsorok, szereplők & 76,3 & 77,7 & 75,0 \\
\hline $\begin{array}{l}\text { Zenei ízlés, zenészek, együtte- } \\
\text { sek }\end{array}$ & 68,5 & 72,1 & 65,1 \\
\hline $\begin{array}{l}\text { Bulváthírek, sztárok, híres } \\
\text { emberek }\end{array}$ & 60,8 & 60,1 & 61,4 \\
\hline \multicolumn{4}{|l|}{ Praktikus témák } \\
\hline Egészség, betegség & 83,7 & 81,1 & 86,1 \\
\hline Családi gazdálkodás, pénz & 66,7 & 61,1 & 72,1 \\
\hline Rokonok életvitele & 63,3 & 61,8 & 64,7 \\
\hline $\begin{array}{l}\text { Szülők munkája, munkahelyi } \\
\text { gondjai }\end{array}$ & 63,3 & 56,3 & 70,0 \\
\hline Másik nemmel való kapcsolat & 60,0 & 57,0 & 62,8 \\
\hline Bûnözés & 58,1 & 52,0 & 63,8 \\
\hline Szegénység & 41,9 & 36,9 & 46,6 \\
\hline Kisebbségek & 41,8 & 37,1 & 46,3 \\
\hline \multicolumn{4}{|l|}{ Elvont témále } \\
\hline Környezetszennyezés & 37,4 & 38,5 & 36,3 \\
\hline Magyarság & 34,3 & 33,5 & 35,7 \\
\hline Vallási, világnézeti kérdések & 27,0 & 26,9 & 27,1 \\
\hline \multicolumn{4}{|l|}{ Politikai témák } \\
\hline Belpolitikai ügyek & 28,9 & 22,6 & 34,8 \\
\hline Politikusok & 26,7 & 21,5 & 31,7 \\
\hline Politikai pártok & 25,9 & 21,5 & 30,1 \\
\hline Külpolitikai ügyek & 24,7 & 20,5 & 28,8 \\
\hline Helyi önkormányzati ügyek & 21,9 & 18,7 & 24,8 \\
\hline Más szervezetek, mozgalmak & 16,1 & 12,9 & 19,1 \\
\hline
\end{tabular}

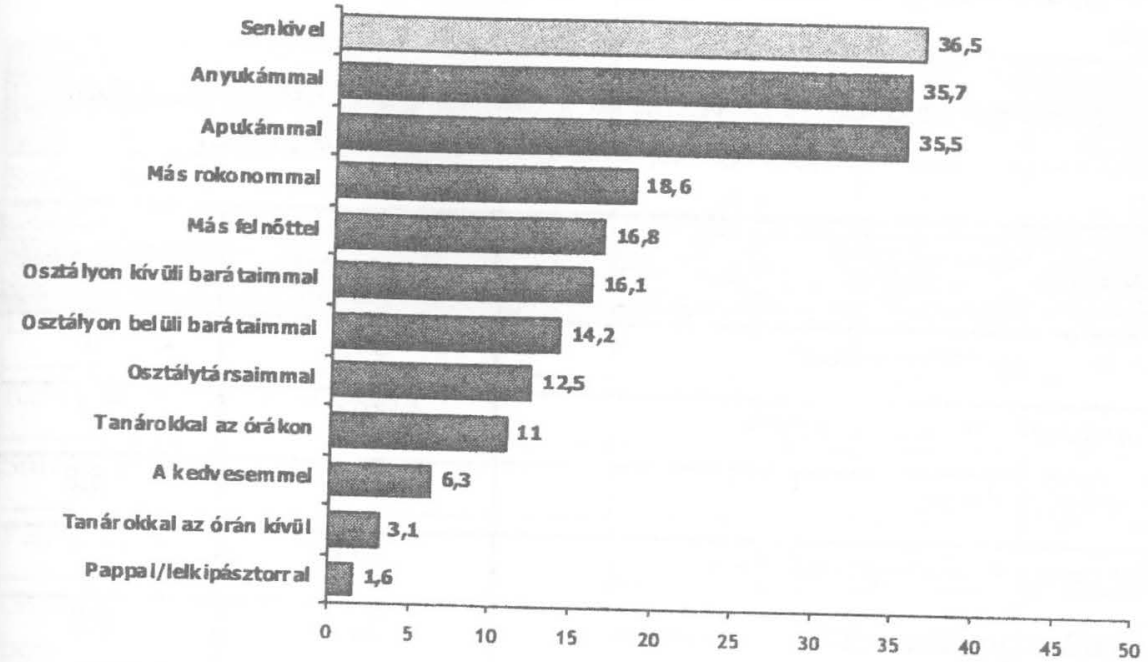

Társadalmi, politikai aktivitás

Hazánkban a rendszerváltozással megszũntek, felbomlottak a korábbi ifjúsági szervezetek, s a rendszerváltást követỏen is müködő nonprofit szervezetek és civil önszervezôdések, társadalmi szervezetek csak csekély mértékben tudják integrálni és mobilizálni az ifjúságot. 1995 óta nô ugyan az ifjúsági civil szervezetek száma, azonban tagságuk folyamatosan csökken (Nagy és Székely 2008:
133-134).

A különbözõ szervezetek és mozgalmak olyan alacsony arányban tudják mozgósítani, „elémi” a fiatalokat, hogy például az Ifjúság2008 kutatás adatai szerint a 18-29 évesek megközelítőleg tizede vett csupán részt valamilyen szervezet vagy mozgalom rendezvényein, hatoduk tagja valamilyen civil szervezetnek, s mindössze körülbelül negyedük ismer egyáltalán valamilyen ifjúsági szervezetet. A politikai ifjúsági szervezetekben való részvételük pedig elenyészó
arányú.

A középiskolások körében készített vizsgálat hasonló eredményeket mutat. Annak ellenére, hogy viszonylag magas cselekvési potenciált mértünk, óriási a szakadék a tervezett és a valós szervezeti tagság között. A válaszadók közül legtöbben $(13,8 \%)$ valamilyen sportegyesületnek a tagjai, valamint $6,4 \%$-uk tagja diákönkormányzatnak, a többi szervezeti tagság elhanyagolható mértékú. Ezzel szemben a „vágyott” tagság kapcsán megállapítható, hogy van olyan szervezet, melynek munkájában a tanulók fele szivesen részt venne. A középiskolások számára a jótékonysági szervezetek, a kömyezetvédó szetvezetek, valamint a 
sportegyesületek a legvonzóbbak. A politikai szféra ifjúság általi elutasítottságát bizonyitja, hogy a tanulók közül legkevesebben politikai pártban lennének tagok.

2. táblázat: A következõ szervezetek közül melyeknek a müködésében vennél részt szivesen, vagy veszel részt jelenleg is? (százalékos megoszlás)

\begin{tabular}{|c|c|c|}
\hline Szenvezetek & Résqt vonnék & Részt veszele \\
\hline Jótékonysági szervezetben & 50,6 & 1,6 \\
\hline Kömyezetvédố szervezetben & 48,8 & 2,1 \\
\hline Sportegyesületben & 46,7 & 13,8 \\
\hline Magyarságot védố egyesületben & 37,0 & 2,4 \\
\hline Az emberi jogokat védố szervezetben & 34,4 & 1,0 \\
\hline Hagyományôrzô egyesületben & 24,5 & 2,7 \\
\hline Fajgyülölet ellen fellépố szervezetben & 22,7 & 1,8 \\
\hline Diákönkotmányzatban & 17,0 & 6,4 \\
\hline Vallási szeretetszolgálatban & 12,8 & 1,9 \\
\hline Politikai pártban & 9,5 & 1,5 \\
\hline
\end{tabular}

Szintén magas cselekvési potenciált mértünk a pártok kampányaiban való egyéni politikai aktivitás kapcsán. Legtöbben, a tanulók harmada szórólaposztással, terjesztéssel járulna hozzá az egyes pártok munkájához, míg negyedük plakátragasztást, illetve e-mail küldést vállalna a kampánytevékenységek közül. A középiskolások megközelitőleg ötöde rendfenntartóként mûködne közre a kampánymunkában. Más feladatokat a hallgatók valamivel több mint tizede vállalna, és ezek közül a szendvicsemberként való segités a legkevésbé vonzó a fratalok számára.

A lányok magasabb arányban járulnának hozzá a pártok kampányához szórólaposztással, terjesztéssel, plakátragasztással és e-mail küldésével, míg a fiúk sívesebben vennének részt a kampánymunkában rendfenntartóként, illetve sziveseben válaszolták, hogy plaḱtépkedést, firkálást vállalnának. Megállapítható továbbá az is, hogy a 11. évfolyamra járók, valamint a gimnazisták szinte az összes tevékenység kapcsán alacsonyabb motivációval rendelkeznek.

3. táblázat: Ha úgy adódna, segitenéd-e valamelyik párt kampányát a kävetkezỏ parlamenti választások elött az alábbi tevékenységekelel? (Az, ,igen" válaszok százalékos megoszlása)

\begin{tabular}{|l|c|c|c|}
\hline Kampányboz leapcsolódé tevékeenységele & $\begin{array}{c}\text { Résquételi sqán- } \\
\text { dék (mintaátlag) }\end{array}$ & 9. êvf. & 11. êvf. \\
\hline Szórólaposztás, terjesztés & 34,7 & 41,9 & 27,9 \\
\hline Plakátragasztás & 26,9 & 32,0 & 22,1 \\
\hline E-mail küldés, továbbítás & 25,4 & 30,9 & 20,3 \\
\hline Rendfenntartóként dolgozni & 18,5 & 20,1 & 16,9 \\
\hline Sms-küldés, továbbítás & 14,7 & 19,4 & 10,3 \\
\hline Plakáttépkedés, firkálás & 15,2 & 18,7 & 11,9 \\
\hline $\begin{array}{l}\text { Gyülés szervezése, részvétel a rendezés- } \\
\text { ben }\end{array}$ & 13,8 & 16,8 & 10,9 \\
\hline Szendvicsember & 12,7 & 15,5 & 10,0 \\
\hline
\end{tabular}

A pártok kampányában való részvételt tekintve a viszonylag magas egyéni aktivitás ambíciója ellenére a középiskolások sok esetben még abban is bizonytalanok, hogy mely pártok a parlamenti ellenzéki párok, melyik párt van kormányon, illetve melyek a parlamenten kívüli pártok. Felmerül a kérdés, hogy ha a tanulók ismerete a fenti dimenzióban való besorolás kapcsán is instabil, menynyire lehetnek tisztában a pártok célkitüzéseivel, programjával, hiszen ezek ismerete nélkül a pártok kampányában való részvétel motivációja megkérdőjelezhetô.

A kutatásba bevont tanulókat arra kértük, hogy hét pártot (FIDESZ, Jobbik Magyarországért, Magyar Demokrata Fórum, Magyar Szocialista Párt, MIÉP, Munkáspárt, SZDSZ) soroljanak be a következô kategóriákba: kormánypárt, parlamenti ellenzéki párt, parlamenten kívüli párt.

Az összes párt kapcsán állást foglaló fiatalok megközelítőleg csupán tizede $(14 \%)$ tudta mind a hét pártról eldönteni helyesen, hogy melyik kategóriába tartozik, míg 51\%-ük négy-hat pártot tudott a megfelelő kategóriába sorolni. A kérdést maradéktalanul megválaszoló középiskolások harmada adott egy-három helyes választ, és $2 \%$-uk egyetlen párt kapcsán sem tudott eligazodni a megadott dimenzióban. A 11. évfolyamosok és a gimnazisták több párt helyét találták meg helyesen a fenti kategóriában, mint a 9. évfolyamosok, illetve a szakközép-, illetve szakiskolások. A három iskolatípus közül a szakiskolába járók ismeretei voltak a legbizonytalanabbak.

A legtöbb tanuló az MSZP-t és a Munkáspártot tudta helyesen besorolni a megadott csoportokba, bát fontos kiemelni, hogy még a kormánypártot is csu- 
pán háromnegyedük ,ismerte fel”. A FIDESZ kapcsán a középiskolások kétharmada tudta helyesen, hogy az parlamenti ellenzéki párt. A legnagyobb bizonytalanságot az SZDSZ kapcsán mértük: a kutatásba bevont fiatalok mindössze valamivel több mint harmada válaszolta, hogy parlamenti ellenzéki párt, és többen voltak azok (53,6\%), akik kormánypártként tartották számon az SZDSZ-t. (Fontos azonban megemlíteni, hogy az adatfelvétel 2008 októbernovemberében zajlott, és a magyar liberális párt 2008 április 30-ával lépett ki a koalícióból.)

4. táblázat: Pártok besoralása a megadott három kategóriába (sqázalékos megoszlás)

\begin{tabular}{|l|c|c|c|}
\hline Pártok & Kormánypárt & $\begin{array}{c}\text { Parlamenti } \\
\text { ellenzéki párt }\end{array}$ & $\begin{array}{c}\text { Parlamenten } \\
\text { kívüli párt }\end{array}$ \\
\hline FIDESZ & 31,0 & 66,6 & 2,4 \\
\hline Jobbik & 11,9 & 20,6 & 67,5 \\
\hline MSZP & 20,6 & 55,8 & 23,6 \\
\hline MIÉP & 75,7 & 15,5 & 8,7 \\
\hline Munkáspárt & 14,9 & 26,2 & 58,9 \\
\hline SZDSZ & 10,0 & 18,5 & 71,4 \\
\hline
\end{tabular}

\section{Összegzés}

A bemutatott kutatatás eredményei alapján megállapítható, hogy a fiatalok politikai érdeklődése és politikai, valamint társadalmi aktivitása alacsonynak mondható, viszont magas cselekvési potenciállal jellemezhetôek a középiskolások. A magas cselekvési potenciál valódi aktivitásban való megnyilvánulásának több korlátja is van. Ezek közül kiemelhetô az ismeretek hiányossága, valamint az, hogy ezt a potenciált a jelenlegi szervezeti keretek nem tudják integrálni.

A vizsgálatnak továbbá fontos tanulsága az is, hogy az iskolatípusok sok esetben differenciálják a politikai szocializáció egyes elemeit. A legnagyobb különbségek a gimnazisták és a szakmunkás tanulók között mérhetôek. Megállapítható, hogy a gimnazisták esetén beszélhetünk a legszinesebb, legváltozatosabb kommunikációs környezetrôl, a politikai témájú diskurzusok az esetükben a legjellemzőbbek, valamint a politikával kapcsolatos tudásuk (legalábbis a pártok világában való tájékozódásuk) magasabb szintủ, mint a más iskolatípusba járó középiskolásoknál. Fontos kiemelni azonban azt is, hogy a politikai aktivi- tással (a páttok kampányában való részvétel kapcsán) az õ esetükben beszélhetünk a legalacsonyabb motivációról.

\section{Irodalom}

Gazsó Ferenc és Laki László (2004): Fiatalok az újkapitalizmusban. Budapest: Napvilág Kiadó. Baucr Béla és Szzabó Andrea (szcrk.) (2005): Ifjúság2004. Gyorsjelentés. Intemeten: http://www.szmi.hu/images/dok/ifjkutatas/ifj2004/iff20041.pdf (letöltve: 2009. november 27.).

Bauer Béla és Szabó Andrea (szerk.) (2009) Ifúság2008 Gyorsjelentés. Intemeten http://www.szmi.hu/imagcs/dok/ifjkutatas/ifjusag2008.pdf - letöltve: 2009. november 26

Szabó Ildikó (2009): A politikeáboz való viszony. Konferencia-előadás. Mit gondolnak a középiskolások a demokráciáról? Konferencia és sajtótájéko’ztató az „Iskola és társadalom, 2008” kutatásról.

Nagy Ádám és Székely Levente (2008): Az ifjúsági civil világ. Civil szemle 5(1-2): 132-149.

\section{Jegyzetek}

${ }^{1}$ A kutatásban az alábbi intézményck vettck részé ELTE TảTK Szociológia Tanszék és OITK, Pécsi Tudományegyetem BTK Szociológia Tanszćk, Szzegedi Tudományegyetem JGyTK Alkalmazott Társadalomtudományi Tanszék, ECHO Survey Szociológiai Kutatóintézet, Debreceni Egyetem BTK Szociológia Tanszék, Debreceni Egyetem Egészségügyi Föiskolai Kar. A vizsgálat vezetô kutatói: Csákó Mihály (ELTE TáTK), Domokos Tamás (ECHO Survey), Kiss Mária Rita (SZTE JGyTK), Murányi István (DE BTK), Sik Domonkos (ELTE TáTK), Szabó Ildikó (DE BTK), Bognár Adrienn (PTE BTK). 